\title{
Genetic Trends in Winter Wheat Yield and Test Weight under Dual-Purpose and Grain-Only Management Systems
}

\author{
Iftikhar H. Khalil, Brett F. Carver,* Eugene G. Krenzer, Charles T. MacKown, and Gerald W. Horn
}

\begin{abstract}
Wheat (Triticum aestivum L.) cultivars of the southern Great Plains are traditionally bred in environments managed for grain production only but are commonly grown for the dual-purpose of producing winter forage and grain from the same crop. To what extent grain yield and test weight are consistently expressed in those environments requires investigation relative to long-term attempts to improve them genetically. A historical set of hard red winter (HRW) wheat cultivars was evaluated under grain-only and dual-purpose management systems to compare their agronomic performance and derived estimates of genetic progress. Separate experiments were established for each system featuring whole-plot treatments of a foliar fungicide and splitplot treatments of 12 cultivars. The study was conducted for $3 \mathrm{yr}$ at the Wheat Pasture Res. Ctr. near Marshall, OK. Dual-purpose experiments were generally grazed from November through February. Yield in the grain-only system improved $18.8 \mathrm{~kg} \mathrm{ha}^{-1} \mathrm{yr}^{-1}$, equivalent to $1.3 \%$ of the mean yield for Turkey. The rate of progress in the dual-purpose system was significantly lower at $11.3 \mathrm{~kg} \mathrm{ha}^{-1} \mathrm{yr}^{-1}$, equivalent to $0.9 \%$ of the mean for Turkey. Management for grazing had a more profound influence on estimates of yield improvement than did management for disease protection. Linear trends in test weight were not evident under either system, nor were cultivar differences influenced by management system consistently across years. Breeding practices should emphasize selection for grain yield in both environments if future progress is to be maximized in both.
\end{abstract}

$\mathrm{W}$ INTER Wheat IN THE southern Great Plains provides a forage pasture resource and a source of grain, often from the same crop. Approximately 3.2 million hectares of hard winter wheat are managed annually for forage and grain (Pinchak et al., 1996). When used for this dual purpose, winter wheat is planted from August to September, grazed by cattle (Bos taurus L.) from November until early March, and harvested for grain in June. Dual-purpose wheat provides high quality forage for stocker cattle during the winter, when other forage sources are low in quantity and quality (Krenzer, 2000).

Wheat cultivars used for dual purpose in the Great Plains are traditionally bred for a grain-only production environment, and hence, may not satisfy expectations for quality and yield of grain produced strictly for that purpose. Grazing, in conjunction with earlier planting, intensifies or prolongs exposure to abiotic and biotic stresses that may not be encountered to the same extent

I.H. Khalil, B.F. Carver, and E.G. Krenzer, Dep. of Plant and Soil Sciences, Oklahoma State Univ., Stillwater, OK 74078; C.T. MacKown, USDA-ARS, Grazinglands Res. Lab., El Reno, OK 73036; and G.W. Horn, Dep. of Animal Sci., Oklahoma State Univ., Stillwater, OK 74078. Published with approval of the Director, Oklahoma Agric. Exp. Stn. Part of a dissertation submitted by I.H. Khalil in partial fulfillment of the Ph.D. degree requirements at Oklahoma State Univ. Received 26 June 2001. *Corresponding author (bfc@mail. pss.okstate.edu).

Published in Crop Sci. 42:710-715 (2002) in a grain-only environment. For example, earlier planting allows earlier infestations of the wheat curl mite (Eriophyes tulipae Keifer) and aphids (Schizaphis graminum Rondani, Rhopalosiphum padi L.), leading to greater pressure from wheat streak mosaic and barley yellow dwarf viruses for which they vector (Wiese, 1991). Root rot diseases are also more prevalent with earlier planting (Cook and Baker, 1983). The continuous removal of forage would conceivably cause greater demand for water and possibly reduce soil-moisture reserves for initiation of grain filling.

Grain yields often decline in an early-planted, forageplus-grain system compared with a later-planted grainonly system. Yield reductions of $30 \%$ in clipped plots (Ud-Din et al., 1993), or 20 to $50 \%$ in grazed plots (Winter and Thompson, 1990; Winter and Musick, 1991), may occur depending on the genotype, severity and termination date of forage removal, and the environment. Some semidwarf cultivars may suffer from a reduced leaf area index at anthesis compared to nonsemidwarfs following grazing (Winter et al., 1990). Reduction in leaf area may reduce delivery of photosynthate and redistribution of accumulated $\mathrm{N}$ to the grain (Mackown and Rao, 1998). Grazing the excess forage in early-planted winter wheat may have minimal effects on grain yield, however, if soil moisture and fertility are adequate, if grazing is terminated before the firsthollow-stem stage, and if leaf regeneration potential is good following cattle removal (Redmon et al., 1995).

Breeders tend to evaluate their materials under a grain-only system, apparently because it is less difficult to manage and less expensive than a forage-plus-grain system, especially one that involves grazing. Genetic modification under a grain-only system may differ from that under a dual-purpose system if the two systems invoke different adaptive mechanisms. Historical genetic gains for winter wheat in the southern Great Plains are typically estimated in grain-only production environments (Cox et al., 1988; Schmidt 1984; Khalil et al., 1995), similar to the environments in which the tested cultivars were selected. These estimates often differ across evaluation environments, and are usually lower under a less productive environment compared with a more productive one (Cox et al., 1988; Feyerherm et al., 1984; Schmidt, 1984). We hypothesized that genetic progress for grain yield and other agronomic traits of HRW wheat may be compromised in a dual-purpose management system. Our objectives were to: (i) measure the effect of an early-planted grazing system on grain yield, yield components, and test weight of a set of cultivars representing several HRW wheat breeding eras, and (ii) estimate and compare genetic progress for grain yield and test weight of HRW wheat cultivars under the two management systems. A fungicide treat- 
ment was included to allow cultivar comparisons with or without the added benefit of foliar disease resistance provided in contemporary cultivars.

\section{MATERIALS AND METHODS}

Twelve HRW wheat cultivars were evaluated during the 1996-1997, 1997-1998, and 1998-1999 crop years (hereafter referred to as 1997, 1998, and 1999, respectively) at the Wheat Pasture Research Center near Marshall, OK. According to their year of release, they were Turkey (1919, as in Cox et al., 1988), Triumph 64 (1964), Scout 66 (1966), TAM W-101 (1971), Vona (1976), TAM 105 (1979), Chisholm (1983), 2157 (1987), 2163 (1989), Karl 92 (1992), Custer (1994), and 2174 (1997). This sample represents some of the most widely grown wheat cultivars throughout the southern Great Plains after the introduction of Turkey. In addition to their direct contribution to wheat production, these cultivars have contributed profusely as parents to wheat breeding programs in the Great Plains.

Two experiments were established each year in a 7- to 10-ha pasture to accommodate independent, but proximate, positioning of dual-purpose and grain-only management systems. The wheat pastures were grazed by stocker cattle as a part of stocking rate or supplementation studies at stocking rates of $2.30,2.06$, and 1.65 steers $\mathrm{ha}^{-1}$ in each of the three years. Additional information relative to dates of grazing initiation, termination, forage mass and forage allowance, growth performance of cattle, and beef production per hectare are shown in Table 1 . The plot area representing the grain-only system was protected from grazing by an electrical fence. As recommended by Krenzer (2000), plots representing the dualpurpose system were planted 3 Sept. 1996 and 1997, and 28 Sept. 1998, with a seeding rate of $77 \mathrm{~kg} \mathrm{ha}^{-1}$, whereas those in the grain-only system were planted 15 Oct. 1996, 7 Oct. 1997, and 16 Oct. 1998 at a seeding rate of $58 \mathrm{~kg} \mathrm{ha}^{-1}$. Grazing termination was determined by the appearance of hollow stem in ungrazed plants of an early-maturing cultivar planted on the same day as the dual-purpose experiment (Redmon et al., 1996).

The soil was a fine, mixed, thermic Udertic Paleustoll (Kirkland silt loam). Nitrogen was applied as anhydrous ammonia across the entire experimental area in amounts considered to be adequate for grain yield of $3000 \mathrm{~kg} \mathrm{ha}^{-1}$ and a dry forage yield of $3500 \mathrm{~kg} \mathrm{ha}^{-1}$ (total $\mathrm{N}$ supply of $220 \mathrm{~kg} \mathrm{ha}^{-1}$ ). Actual applied $\mathrm{N}$ was adjusted for residual mineral nitrogen in the top $60 \mathrm{~cm}$ of soil each year. Fertilizer applications for both systems were dictated by requirements of the dual-purpose system, thus providing more $\mathrm{N}$ in the grain-only system than the yield goal, since forage was not removed. However, this amount was believed to exceed $\mathrm{N}$ requirements for grain yield historically measured at this site $\left(<3500 \mathrm{~kg} \mathrm{ha}^{-1}\right)$. Soil phosphorus and potassium were adequate for the target grain and forage yields during all years. Soil $\mathrm{pH}$ was 5.5 during the first two years, and 4.7 in the third year. The plot area was limed with $2500 \mathrm{~kg} \mathrm{ha}^{-1}$ ECCE (effective calcium carbonate equivalent) in July 1998

The experimental design for each system was a split-plot with five replicates of the two whole plots (foliar fungicide vs. no fungicide) and 12 cultivars as subplots. The foliar fungicide propiconazole, 1-[[2-(2,4-dichlorophenyl)-4-propyl-1,3-dioxolan-2-yl]methyl]-1H-1,2,4-triazole, was applied $(292 \mathrm{~mL}$ a.i. $\mathrm{ha}^{-1}$ ) at wheat growth stage 8 , or approximately at flag leaf emergence (Large, 1954), and about 2 wk later. This fungicide controlled the two predominant foliar diseases, leaf rust caused by Puccinia triticina Eriks. and Septoria leaf blotch caused by Septoria tritici Roberge in Desmaz. Each subplot was $3 \mathrm{~m}$ long with five rows spaced $23 \mathrm{~cm}$ apart. All five rows per subplot were combine-harvested on the same day. We measured grain yield as weight of threshed, cleaned grain; test weight from a $0.95-\mathrm{L}$ container according to standard procedures; spike density as number of spikes per meter squared counted from a $0.5-\mathrm{m}$ section in one of the three middle rows; kernels per spike as mean number of kernels from 15 randomly selected spikes; and 1000-kernel weight calculated from the mean kernel weight of the 15 random spikes. Grain yield, 1000-kernel weight, and kernels per spike were measured in all replicates, whereas test weight and spike density were measured in three or four of the five replicates.

Data were analyzed across years and systems by means of a mixed model. Systems, fungicide treatments, and cultivars were considered as fixed effects; replications and years were considered random. The respective error term for each $F$-test was estimated with the random statement in PROC GLM of SAS (SAS Institute, 2000). The sum of squares associated with cultivars in the combined analysis of variance, or in the analysis within systems, fungicide treatments, or years, was partitioned into sources representing linear regression on year of release and deviations from regression. The coefficient of regression served as an estimate of genetic progress for a given attribute in a specific environment. Heterogeneity of regression coefficients between systems was determined from the significance of system $\times$ cultivar linear interactions. Similarly, the heterogeneity of regression coefficients between fungicide and no-fungicide treatments was determined from the significance of the fungicide $\times$ cultivar linear interaction in

Table 1. Features of the dual-purpose management system applied to wheat pastures at Marshall, OK, for $3 \mathrm{yr}$.

\begin{tabular}{|c|c|c|c|}
\hline Item & 1996-1997 & 1997-1998 & 1998-1999 \\
\hline Total pasture area, ha $\dagger$ & 7.3 & 9.7 & 8.5 \\
\hline Grazing initiation & 25 Oct. 1996 & 25 Oct. 1997 & 17 Nov. 1998 \\
\hline Grazing termination & 24 Feb. 1997 & 20 Feb. 1998 & 6 Mar. 1999 \\
\hline Grazing period, $d$ & 122 & 118 & 109 \\
\hline Stocking rate, steer ha $\mathbf{h}^{-1}$ & 2.30 & 2.06 & 1.65 \\
\hline Stocking rate, kg steer $\mathrm{ha}^{-1} \ddagger$ & 651 & 593 & 449 \\
\hline \multirow[t]{4}{*}{ Available dry matter forage, $\mathrm{kg} \mathrm{ha}^{-1}$} & 1871 (23 Oct.) & 1723 (24 Oct.) & - \\
\hline & 2450 (5 Dec.) & 3363 (12 Dec.) & 2358 (9 Dec.) \\
\hline & 1154 (20 Jan.) & 1211 (20 Jan.) & 3022 (11 Jan.) \\
\hline & 651 (14 Feb.) & 566 (17 Feb.) & 2818 (5 Feb.) \\
\hline Available dry matter forage per & 402 (23 Oct.) & 389 (24 Oct.) & - \\
\hline \multirow{3}{*}{$100 \mathrm{~kg}$ steer body wt., kg } & 355 (5 Dec.) & 611 (12 Dec.) & 697 (9 Dec.) \\
\hline & 174 (20 Jan.) & 180 (20 Jan.) & 626 (11 Jan.) \\
\hline & 96 (14 Feb.) & 80 (17 Feb.) & 401 (5 Feb.) \\
\hline Steer wt. gain, $\mathbf{k g ~ d}^{-1}$ & 0.95 & 1.08 & 1.08 \\
\hline Steer wt. gain, kg steer ${ }^{-1}$ & 116 & 127 & 118 \\
\hline Beef gain, $\mathrm{kg} \mathrm{ha}^{-1}$ & 267 & 262 & 194 \\
\hline
\end{tabular}

$\dagger$ Includes experimental plot area of 0.14 ha.

$\$$ Based on mean weight of the cattle during the entire grazing trial. 
the analysis of variance across years for each system. Corresponding residual mean squares for each interaction served as error terms in the $F$-tests. Least significant difference (LSD) values were calculated to compare means for the same cultivar between the two systems with year $\times$ system $\times$ cultivar mean squares as the error term.

\section{RESULTS AND DISCUSSION}

Genetic variation for grain yield and test weight was highly significant $(P<0.01)$, as expected from a diverse genotypic sample spanning nearly $80 \mathrm{yr}$ of genetic improvement (Table 2). Means across years for the two systems were not significantly different for yield $(P=$ $0.24)$ or for test weight $(P=0.83)$, given the presence of large system $\times$ year interactions. Fungicide application did not affect grain yield, nor did the fungicide treatment interact with other factors. Fungicide application did influence test weight and show interactions with systems and cultivars.

\section{Environmental Conditions}

The 3-yr test period provided diverse environmental conditions from which differences in mature plant development were readily detected. The grazing period during the first year (1997), when demand often exceeded forage availability (Table 1), was followed by an unusually late freeze (mean daily temperature $\leq 1.4^{\circ} \mathrm{C}$ ) from 10 to 13 April 1997, when early maturing cultivars were either in the late-boot stage or at heading. This sequence of severe defoliation and freeze conditions was followed by the lowest grain yield among the three years. For the second year (1998), weather conditions were excellent for wheat growth, resulting in record statewide grain yields (Oklahoma Agric. Stat. Serv., 1998). Grain

Table 2. Mean squares for grain yield and test weight of 12 winter wheat cultivars evaluated under grain-only and dual-purpose systems with and without fungicide for 3 yr at Marshall, $O K$.

\begin{tabular}{|c|c|c|c|}
\hline Source of variation & df & Grain yield & Test weight \\
\hline & & $\left(\mathrm{kg} \mathrm{ha}^{-1}\right)^{2} \times 10^{4}$ & $\left(\mathrm{~kg} \mathrm{hL}^{-1}\right)^{2}$ \\
\hline Year (Y) & 2 & 15856 & 176981 \\
\hline System (S) & 1 & 6167 & 952 \\
\hline $\mathbf{Y} \times \mathbf{S}$ & 2 & 1270 ** & $18041^{* *}$ \\
\hline $\operatorname{Reps}(\mathbf{Y} \times \mathbf{S})$ & $24(16) \dagger$ & 70 & 1728 \\
\hline Fungicide (F) & 1 & 433 & $13018^{*}$ \\
\hline $\mathbf{Y} \times \mathbf{F}$ & 2 & 24 & 667 \\
\hline $\mathbf{S} \times \mathbf{F}$ & 1 & 110 & $343 * *$ \\
\hline $\mathbf{Y} \times \mathbf{S} \times \mathbf{F}$ & 2 & 52 & 7 \\
\hline $\mathbf{F} \times \operatorname{Reps}(\mathbf{Y} \times \mathbf{S})$ & 24 (16) & 19 & 367 \\
\hline Cultivar (C) & 11 & $776^{* *}$ & $11338 * *$ \\
\hline C linear & $\mathbf{1}$ & $6616 * *$ & 2088 \\
\hline $\mathbf{Y} \times \mathbf{C}$ & 22 & $189 * *$ & 874 \\
\hline $\mathbf{Y} \times \mathbf{C}$ linear & 2 & $480 * *$ & 204 \\
\hline $\mathbf{S} \times \mathbf{C}$ & 11 & 90 & 446 \\
\hline $\mathbf{S} \times \mathbf{C}$ linear & 1 & $410 *$ & 1 \\
\hline $\mathbf{F} \times \mathbf{C}$ & 11 & 21 & $773 *$ \\
\hline $\mathbf{F} \times \mathbf{C}$ linear & 1 & 20 & 1139 \\
\hline $\mathbf{Y} \times \mathbf{S} \times \mathbf{C}$ & 22 & $60 * *$ & $941 * *$ \\
\hline $\mathbf{Y} \times \mathbf{S} \times \mathbf{C}$ linear & 2 & 268 ** & $4952 * *$ \\
\hline Pooled interactions & 55 & 76 & 784 \\
\hline Pooled error & $528(352)$ & 19 & 278 \\
\hline C.V. (\%) & & 19.2 & 2.2 \\
\hline
\end{tabular}

* Indicates significance at $\boldsymbol{P}=\mathbf{0 . 0 5}$.

** Indicates significance at $\boldsymbol{P}=\mathbf{0 . 0 1}$.

$\dagger$ Degrees of freedom for test weight.

\pm Includes (with df) $\mathbf{Y} \times \mathbf{F} \times \mathbf{C}(\mathbf{2 2})+\mathbf{S} \times \mathbf{F} \times \mathbf{C}$ (11) $+\mathbf{Y} \times \mathbf{S} \times \mathbf{F} \times$ $\mathrm{C}$ (22), which were non-significant. yields were likely influenced by barley yellow dwarf virus infection. Symptoms were more visible in the dualpurpose system for all cultivars. Good moisture and mild winter temperatures during the third year (1999) led to high forage production. Symptoms of soil-borne mosaic were observed in the grain-only system but not in the dual-purpose system. This disease likely affected grain yield, except for the resistant cultivars 2157, 2163 , Karl 92, and 2174. Summarizing across the three years, grazing-induced defoliation varied from extremely severe in 1997, with negligible green vegetation remaining at the time of cattle removal, to mild in 1999, with little discernible difference in canopy height between systems at cattle removal.

\section{Grain Yield Responses}

During the first two years of this study $(1997,1998)$, no cultivar produced greater yield in the dual-purpose system than in the grain-only system (Fig. 1). The grain

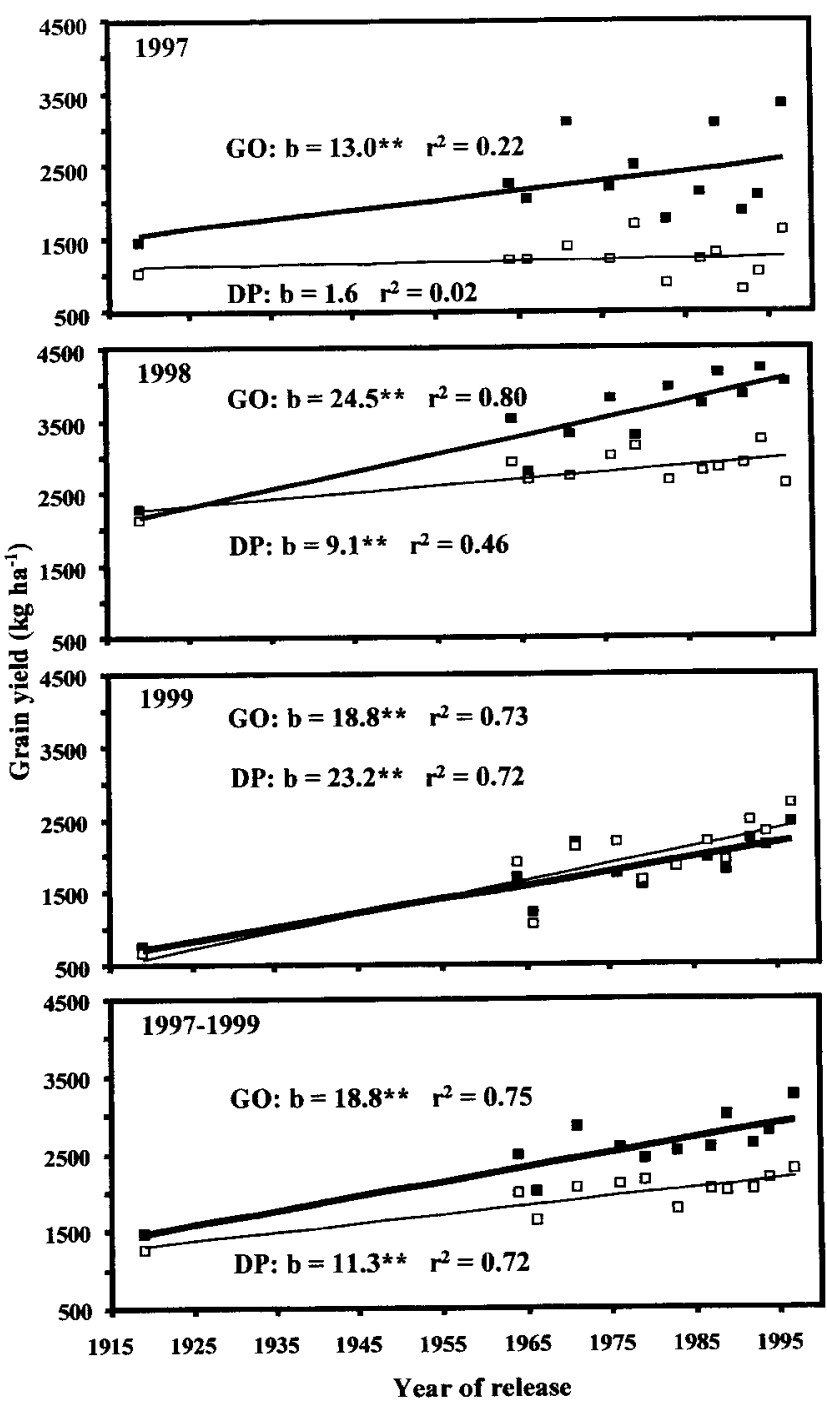

Fig. 1. Linear regression on year of release for grain yield of 12 hard red winter wheat cultivars (averaged across fungicide treatments) under grain-only (GO, solid squares and thick line) and dualpurpose (DP, open squares and thin line) systems in 1997, 1998, 1999, and averaged across 3 yr at Marshall, OK. 
yield reduction in the dual-purpose system varied among cultivars from 30 to $60 \%$ in 1997, averaging $49 \%$, and from 4 to $35 \%$ in 1998, averaging 22\% (Table 3 ). For the third year (1999), yields were virtually identical between systems for each cultivar (Fig. 1). Forage production that year exceeded the demand imposed by grazing, even at a higher stocking rate, leaving ample vegetative reserves for grain production following cattle removal (Table 1). This disparity in yearly patterns was reflected in the significant year $x$ system and year $X$ system $\times$ cultivar interactions shown in Table 2 . When a consistent yield difference was observed between systems for each cultivar, as it was in 1997 and 1998, the dual-purpose system showed less yield.

Averaging across years for each cultivar, the reduction in grain yield varied from $12 \%$ for TAM 105 to $33 \%$ for 2163 . These two cultivars represent semidwarf genotypes, released only $10 \mathrm{yr}$ apart. Yield reductions were not highly correlated with year of release $(r=$ $0.50, P=0.10)$, nor did they appear to be accentuated in the newer semidwarf genotypes. Yield reductions for the three tall, non-semidwarf cultivars (Turkey, Scout 66 , and Triumph 64) varied between 15 and $20 \%$ and were within the range observed for the semidwarf cultivars. With a limited sample of one tall and two semidwarf cultivars, Winter et al. (1990) suggested a possible adaptive advantage for non-semidwarf cultivars in a dual-purpose system. Their greater height was believed to offer comparatively more leaf area at heading than the semidwarf cultivars, and potentially greater recovery from grazing. Leaf area index of these three cultivars at anthesis and grain yields of the two semidwarf cultivars increased linearly with increasing biomass at anthesis, whereas grain yield of the tall cultivar did not increase beyond an anthesis biomass of $1300 \mathrm{~g} \mathrm{~m}^{-2}$ (Winter and Musick, 1991).

With cultivars treated as a qualitative factor, the nonsignificant system $\times$ cultivar mean square in Table 2 would imply that management system had no significant effect on separation of cultivars. The phenotypic correlation between systems was high $(r=0.89, P<0.01)$, indicating similarity of cultivar responses. With year of release as a quantitative indicator of their expected level of improvement, linear functions of cultivar yields (i.e., rate of genetic improvement) differed markedly between systems, again with year effects (Table 2 , system $\times$ cultivar linear, year $\times$ system $\times$ cultivar linear terms, $P<$ $0.05)$. Rates were significantly greater in the grain-only system than in the dual-purpose system in 1997 and 1998 (Table 3). Recent cultivars performed better than older ones, but the rate of improvement was clearly suppressed under dual-purpose management. Only in 1999 were rates similar between systems, when grazing pressure was low relative to forage availability. Interestingly, no significant progress was detected as a linear trend in the dual-purpose system in 1997, when mean yield in that system was greatly reduced compared to other years. These 12 cultivars were included in another experiment in 2000 , and treated entirely with propiconazole fungicide. Rates of improvement estimated under the fungicide treatment in 2000 (not shown) were 30.2 (grain-only) and $20.9 \mathrm{~kg} \mathrm{ha}^{-1} \mathrm{yr}^{-1}$ (dual-purpose), and these differed significantly between systems.

Genetic improvement in the grain-only system averaged across the 3 -yr period was $18.8 \mathrm{~kg} \mathrm{ha}^{-1} \mathrm{yr}^{-1}$, equivalent to $1.3 \%$ of the mean yield for Turkey, or $0.7 \%$ of the mean of all cultivars. Improvement in the dualpurpose system was significantly lower at $11.3 \mathrm{~kg} \mathrm{ha}^{-1}$ $\mathrm{yr}^{-1}$, equivalent to $0.9 \%$ of the mean for Turkey, or $0.6 \%$ of the mean of all cultivars. We also estimated genetic improvement without the cultivar Turkey included in the regression analysis, because of the potentially inordinate influence it may have on least-squares estimates of the regression coefficient. The 45-year gap between Turkey and Triumph 64 well exceeded the mean 3.3-yr gap between subsequent pairs of consecutive cultivars. Exclusion of Turkey did not change the regression coefficient in the grain-only system, but the average rate in the dual-purpose system was even further reduced from 11.3 to $8.8 \mathrm{~kg} \mathrm{ha}^{-1} \mathrm{yr}^{-1}(P<0.05$, $\left.r^{2}=0.30\right)$.

The genetic superiority of contemporary cultivars is derived not only from their higher yield potential per se but also from their greater resistance to foliar diseases. Cultivars developed in the Great Plains routinely express some degree of resistance to the most prevalent fungal disease, leaf rust. Leaf rust resistance has been shown to provide a significant yield advantage in the southern Great Plains (Cox et al., 1997; Martin et al., 1999) and elsewhere (Sayre et al., 1998). Cultivars known in this study to possess effectively higher levels of resistance were Custer and 2174. The foliar fungicide, propiconazole, was applied prior to the kernel filling period to provide equal protection to all cultivars from leaf rust and from Septoria leaf blotch. Symptoms of these diseases, particularly for leaf rust, were observed

Table 3. Means and genetic improvement, estimated by linear regression on year of cultivar release, for grain yield and test weight for 12 winter wheat cultivars evaluated under grain-only (GO) and dual-purpose (DP) systems for 3 yr at Marshall, OK.

\begin{tabular}{|c|c|c|c|c|c|c|c|c|c|}
\hline \multirow[b]{2}{*}{ Characteristic } & \multirow[b]{2}{*}{ System $\dagger$} & \multicolumn{4}{|c|}{ Mean } & \multicolumn{4}{|c|}{ Rate of improvement per year } \\
\hline & & 1996-1997 & 1997-1998 & 1998-1999 & All years & 1996-1997 & 1997-1998 & 1998-1999 & All years \\
\hline Grain yield $\left(\mathrm{kg} \mathrm{ha}^{-1}\right)$ & GO & 2240 & 3560 & 1800 & 2533 & 13.0*** & $24.5 * *$ & $18.8 * *$ & $18.8^{* *}$ \\
\hline & DP & 1140 & 2790 & 1910 & 1947 & 1.6 & $9.1 * *$ & 23.2** & 11.3 ** \\
\hline$P$-value for comparing systems & & & & & 0.24 & 0.01 & 0.01 & 0.23 & 0.02 \\
\hline Test weight $\left(\mathrm{kg} \mathrm{hL}^{-1}\right)$ & GO & 77.7 & 79.3 & 71.9 & 76.3 & $0.23 * *$ & $0.30 * *$ & $-0.19 *$ & 0.05 \\
\hline & DP & 75.7 & 78.4 & 73.7 & 75.9 & -0.13 & 0.06 & $0.37 * *$ & 0.15 \\
\hline$P$-value for comparing systems & & & & & 0.83 & 0.01 & 0.01 & 0.01 & 0.52 \\
\hline
\end{tabular}

* Indicates significance at $\boldsymbol{P}=\mathbf{0 . 0 5}$

** Indicates significance at $\boldsymbol{P}=\mathbf{0 . 0 1}$.

$\dagger$ Each system included foliar fungicide and no-fungicide treatments in its average.

+ Statistical comparison of within-year means was not attempted due to lack of true error term; comparison of regression coefficients based on significance of system $\times$ cultivar linear interaction. 
Table 4. Means and genetic improvement, estimated by linear regression on year of cultivar release, for grain yield and test weight for 12 winter wheat cultivars with or without foliar fungicide and evaluated in grain-only (GO) and dual-purpose (DP) systems for 3 yr at Marshall, OK.

\begin{tabular}{|c|c|c|c|c|c|}
\hline \multirow[b]{2}{*}{ Characteristic } & \multirow[b]{2}{*}{ Treatment } & \multicolumn{2}{|c|}{ Mean } & \multicolumn{2}{|c|}{ Rate of improvement per year } \\
\hline & & GO & DP & GO & DP \\
\hline \multirow[t]{2}{*}{ Grain yield $\left(\mathrm{kg} \mathrm{ha}^{-1}\right)$} & No-fungicide & 2420 & 1910 & $18.9 * *$ & $9.5 * *$ \\
\hline & Fungicide & 2650 & 1990 & $18.6^{* *}$ & 13.1** \\
\hline Comparison between treatments $\dagger$ & & NS & NS & NS & NS \\
\hline \multirow{2}{*}{ Test weight ( $\left.\mathrm{kg} \mathrm{hL}^{-1}\right)$} & No fungicide & 75.4 & 75.6 & 0.01 & 0.00 \\
\hline & Fungicide & 77.2 & 76.2 & 0.08 & 0.30 \\
\hline Comparison between treatments & & $*$ & NS & NS & NS \\
\hline
\end{tabular}

* Indicates significance at $P=0.05$.

** Indicates significance at $\boldsymbol{P}=\mathbf{0 . 0 1}$.

$\dagger$ Comparison of regression coefficients based on significance of fungicide $\times$ cultivar linear interaction across years under each system.

in all years in the absence of fungicide, though specific reactions for each cultivar were not quantified. Even with those diseases mitigated, the fungicide treatment provided no significant yield benefit (Tables 2 and 4), nor were interactions with systems or cultivars significant (Table 2). Genetic improvement measured in the grain-only system was almost identical in the absence or presence of fungicide (about $19 \mathrm{~kg} \mathrm{ha}^{-1} \mathrm{yr}^{-1}, P<$ 0.01 ), and similar between fungicide treatments in the dual-purpose system (9.5 to $13.1 \mathrm{~kg} \mathrm{ha}^{-1} \mathrm{yr}^{-1}, P<0.01$, Table 4). Hence across years, management for grazing had a more profound influence on estimates of yield progress than did management for fungal-disease protection.

Yield losses in the dual-purpose system, either as an average across cultivars or as an estimate of genetic improvement, could not be attributed to physical removal of reproductive tissues by grazing, expressed as reduced spike density. Cattle removal always preceded the first appearance of hollow stem above the crown, as defined by Redmon et al. (1996). Consider, for example, two cultivars with extreme values for yield loss, TAM 105 (lowest yield loss from grain-only to dual-purpose) and 2163 (highest loss). Despite this disparity, each cultivar produced similar numbers of fertile spikes between the two systems: 507 vs. 531 spikes $\mathrm{m}^{-2}$ for TAM 105 in grain-only vs. dual-purpose systems, and 459 vs. 448 spikes $\mathrm{m}^{-2}$ for 2163 . System means for all cultivars were equal, or about 515 spikes $\mathrm{m}^{-2}$ (Table 5). In contrast, changes in the number of kernels per spike and kernel weight were unidirectional, with lower values consistently found in the dual-purpose system. Each cultivar produced 1 to 4 fewer kernels per spike in the dualpurpose system, and the two systems averaged 27 (grainonly) vs. 25 (dual-purpose) kernels per spike $(P=0.26)$.
Each cultivar also had lower 1000-kernel weight by 0.5 to $2.7 \mathrm{~g}$, with system means of 32.2 (grain-only) vs. $30.5 \mathrm{~g}$ (dual-purpose) $(\mathrm{P}=0.11)$.

While no single yield component may account for the different yield patterns between systems, the discussion above would imply that the combination of, or product of, kernel number per spike and kernel weight, i.e., grain weight per spike, is a key yield determinant in the dualpurpose environment. Losses in the dual-purpose system varied from 87 to $161 \mathrm{mg}$ per spike among cultivars, with mean grain weights of $880 \mathrm{mg}$ per spike for the grain-only system and $758 \mathrm{mg}$ per spike for the dualpurpose system (Table 5). Genetic improvement was significant, averaging 3.2 and $2.8 \mathrm{mg}$ per spike $\mathrm{yr}^{-1}$ in the grain-only and dual-purpose systems across years, respectively. The lower yields in the dual-purpose system reflected lower spike weights for all cultivars, but the rate of progress was still parallel between systems. The lack of response in spike density, combined with a reduction in grain weight per spike, would seem plausible if the dual-purpose system did not reduce tiller survival but decreased photosynthate production during kernel filling as a consequence of reduced biomass and source capacity at heading. Further research is in progress to quantify source-sink interactions responsible for the differential yield gains.

\section{Test Weight Responses}

Cultivar differences were observed for test weight, but these differences varied depending on the system or year in which they were measured (Table 2). During the first two years, test weights of all cultivars tended to be higher (1 to $3 \%$ ) in the grain-only system than the dual-purpose system, but the reverse was true in

Table 5. Means and genetic improvement, estimated by linear regression on year of cultivar release, for spike density and spike weight for 12 winter wheat cultivars evaluated under grain-only (GO) and dual-purpose (DP) systems for 3 yr at Marshall, OK.

\begin{tabular}{|c|c|c|c|c|c|c|c|c|c|}
\hline \multirow[b]{2}{*}{ Characteristic } & \multirow[b]{2}{*}{ System $\dagger$} & \multicolumn{4}{|c|}{ Mean } & \multicolumn{4}{|c|}{ Rate of improvement per year } \\
\hline & & 1996-1997 & 1997-1998 & 1998-1999 & All years & 1996-1997 & 1997-1998 & 1998-1999 & All years \\
\hline \multirow[t]{2}{*}{ Spike density (spikes $\mathrm{m}^{-2}$ ) } & GO & 462 & 568 & 511 & 514 & -1.1 & -1.2 & -0.9 & $-\mathbf{1 . 0}$ \\
\hline & DP & 413 & 529 & 604 & 516 & -0.2 & -0.6 & -0.8 & -0.5 \\
\hline$P$-value for comparing systems $\ddagger$ & & & & & 0.97 & NS & NS & NS & NS \\
\hline \multirow{2}{*}{ Spike weight (mg) } & GO & 691 & 894 & 1056 & 880 & $3.2 * *$ & $3.7 * *$ & $2.8 * *$ & $3.2 * *$ \\
\hline & DP & 527 & 887 & 860 & 758 & 1.1 & $3.4 * *$ & $3.9 * *$ & $2.8 * *$ \\
\hline$P$-value for comparing systems & & & & & 0.17 & 0.01 & NS & NS & NS \\
\hline
\end{tabular}

** Significant at $\boldsymbol{P}=\mathbf{0 . 0 1}$.

$\dagger$ Each system included foliar fungicide and no-fungicide treatments in its average.

† Statistical comparison of within-year means was not attempted because of lack of true error term; comparison of regression coefficients based on significance of system $\times$ cultivar linear interaction. 
1999. Hence, no difference was found between system means averaged across years (Table 3 ). Test weights were highly correlated $(r=0.96, P<0.01)$ between systems, indicating a high level of consistency. The benefit of a foliar fungicide application was observed only in the grain-only system, where test weight increased by $3 \%$ (Table 4 ). No significant change was detected in the dual-purpose system.

Genetic improvement in test weight was significant, and greater in the grain-only system than the dual-purpose system in 1997 and 1998 (Table 3); but, in 1999, a genetic decline occurred in the grain-only system. Results from 2000, only with the fungicide treatment, showed zero gains in both systems (data not shown). Averaged across years (1997-1999), improvement in test weight was not evident in either system (Table 3 ). Gains in test weight were likewise zero, either with or without fungicide protection (Table 4). While test weight did not show the same level of improvement as grain yield, it did not suffer the same degree of reduction in the dual-purpose system. The general lack of progress could be attributed to a lower emphasis on test weight than grain yield during cultivar development, the difficulty in improving both grain yield and test weight simultaneously, or selection practices that traditionally emphasize a constant threshold level rather than incremental increases in test weight.

\section{CONCLUSIONS}

With the addition of improved semidwarf cultivars commercialized in the past decade $(2157,2163$, Karl 92, Custer, and 2174), our estimate of breeding progress for grain yield in the conventional grain-only system$18.8 \mathrm{~kg} \mathrm{ha}^{-1} \mathrm{yr}^{-1}$, or $1.4 \%$ per year of the mean of Turkey-was consistent with an estimate by Cox et al. (1988) of $16.2 \mathrm{~kg} \mathrm{ha}^{-1} \mathrm{yr}^{-1}$, or $1.0 \%$ of Turkey. Hence, genetic progress continues for grain yield of HRW wheat, particularly in an environment managed strictly for grain production. Progress in test weight was not detected in this genetic sample. Long-term trends in the Oklahoma State University wheat breeding program generated the same conclusion (Khalil et al., 1995).

Superiority in the grain-only system among contemporary cultivars was similarly expressed in the dualpurpose system, but with a yield penalty as high as 33\% and no penalty for test weight. Continued selection in a grain-only system will likely deliver benefits (for grain yield) to a producer using newly developed cultivars in a dual-purpose system. Reducing the yield penalty will, however, require a targeted approach of selection for adaptive characteristics unique to a dual-purpose environment. Among those discussed in more detail by Carver et al. (2001, p. 463), the capacity to recover rapidly from defoliation immediately preceding culm elongation appears to warrant special attention. Rather than establish independent breeding programs for each management system, we suggest an integrative approach of identifying populations, and lines derived from those populations, that are best adapted to a dual-purpose management system but express high yield potential under a grain-only system.

\section{ACKNOWLEDGMENTS}

The authors gratefully acknowledge the technical assistance of Wayne Whitmore. This research was supported by USDACSREES, Agreement numbers 97-34198-3970 and 99-341987481, the Oklahoma Wheat Research Foundation, and the Oklahoma Agricultural Experiment Station.

\section{REFERENCES}

Carver, B.F., A.R. Klatt, and E. G. Krenzer, Jr. 2001. The North American wheats: U.S. hard winter wheat pool. p. 445-467. In A.P. Bonjean and W.J. Angus (ed.) The world wheat book: A history of wheat breeding. Lavoisier Publ., Paris.

Cook, R.J., and K.F. Baker. 1983. The nature and practice of biological control of plant pathogens. Am. Phypathol. Soc., St. Paul, MN.

Cox, T.S., R.K. Bequette, R.L. Bowden, and R.G. Sears. 1997. Grain yield and breadmaking quality of wheat lines with the leaf rust resistance gene Lr41. Crop Sci. 37:154-161.

Cox, T.S., J.P. Shroyer, L. Ben-Hui, R.G. Sears, and T.J. Martin. 1988. Genetic improvement in agronomic traits of hard red winter wheat cultivars from 1919 to 1987. Crop Sci. 28:756-760.

Feyerherm, A.M., G.M. Paulsen, and J.L. Sebaugh. 1984. Contribution of genetic improvement to recent wheat yield increases in the USA. Agron. J. 76:985-990.

Khalil, I.H., B.F. Carver, and E.L. Smith. 1995. Genetic gains in two selection phases of a wheat-breeding programme. Plant Breed. 114: 117-120.

Krenzer, E.G. 2000. Wheat as forage. p. 27-30. In T.A. Royer and E.G. Krenzer (ed.) Wheat management in Oklahoma. Oklahoma Coop. Ext. Serv. and Oklahoma Agric. Exp. Stn. E-831.

Large, E.C. 1954. Growth stages in cereals: Illustration of the Feekes scales. Plant Pathol. 3:128-129.

MacKown, C.T., and S.C. Rao. 1998. Source-sink relations and grain quality of winter wheat used for forage and grain production. p. 148. In Agron. abstr. ASA, Madison, WI.

Martin, J., B.F. Carver, and R.M. Hunger. 1999. Gene effects and interactions for leaf rust response and awn type in winter wheat. p. 70. In Agron. abstr. ASA, Madison, WI.

Oklahoma Agricultural Statistics Service. 1998. Oklahoma Agricultural Statistics. Oklahoma Dep. of Agric., Oklahoma City, OK.

Pinchak, W.E., W.D. Worral, S.P. Caldwell, L.J. Hunt, H.J. Worral, and M. Conoly. 1996. Interrelationships of forage and steer growth dynamics on wheat pasture. J. Range Manage. 49:126-130.

Redmon, L.A., G.W. Horn, E.G. Krenzer, Jr., and D.J. Bernardo 1995. A review of livestock grazing and wheat grain yield: Boom or bust? Agron. J. 87:137-147.

Redmon, L.A., E.G. Krenzer, Jr., D.J. Bernardo, and G.W. Horn. 1996. Effect of wheat morphological stage at grazing termination on economic return. Agron. J. 88:94-97.

SAS Institute. 2000. SAS user's guide. Release 8.10. SAS Inst., Cary, NC.

Sayre, K.D., R.P. Singh, J. Huerta-Espino, and S. Rajaram. 1998. Genetic progress in reducing losses to leaf rust in CIMMYT-derived Mexican spring wheat cultivars. Crop Sci. 38:654-659.

Schmidt, J.W. 1984. Genetic contributions to yield gains in wheat. p. 89-101. In W.R. Fehr (ed.) Genetic contributions to yield gains of five major crop plants. CSSA Spec. Publ. 7. CSSA, ASA, Madison, WI.

Ud-Din, N., B.F. Carver, and E.G. Krenzer, Jr. 1993. Visual selection for forage yield in winter wheat. Crop Sci. 33:41-45.

Wiese, M.V. 1991. Compendium of wheat diseases. 2nd ed. APS Press. Am. Phytopathol. Soc., St. Paul, MN.

Winter, S.R., and J.T. Musick. 1991. Grazed wheat grain yield relationships. Agron. J. 83:130-135.

Winter, S.R., and E.K. Thompson. 1990. Grazing winter wheat: I. Response of semidwarf cultivars to grain and grazed production systems. Agron. J. 82:33-37.

Winter, S.R., E.K. Thompson, and J.T. Musick. 1990. Grazing winter wheat: II. Height effects on response to production system. Agron. J. 82:37-41. 